Research article

\title{
Role of farmer's indigenous knowledge for adaptation and mitigation to climate change in Kgalagadi-North District, Botswana
}

\author{
S. Mabula and A. Angassa* \\ Botswana University of Agriculture and Natural Resources, Faculty of Natural Resources, Department of Range and Forest \\ Resources, Private Bag 0027, Gaborone, Botswana
}

ARTICLE INFORMATION

\section{Keywords}

Indigenous knowledge

Climate Change

Adaptation

Mitigation

Vulnerability

Article History:

Submission date: 22 Sep. 2019

Revised: 06 Dec. 2019

Accepted: 20 Jan. 2020

Available online: 04 Apr. 2020

https://bojaas.buan.ac.bw

Corresponding Author:

*A. Angassa
ㅇㅛㅛ : (+267) 3650701
䀏 : (+267) 3928753
: aabdeta@buan.ac.bw

Abstract: This paper presents perceptions of farmers in terms of adaptation and mitigation to climate change in Kgalagadi-North District. The study used a qualitative survey method and results were derived from purposively selected interviews using semi-structured questionnaire. The research focused on participants who were aged 50 years and above. Data were summarized and analysed qualitatively using descriptive statistics. Perceptions of farmers showed that frequent wildfire was a major cause of climate change. Farmers further stated that they were affected by irregular rainfall, increased temperature and recurrent droughts. The findings confirmed that the milk production and number of calves per cows were in a declining trend over the last 30 years. The results showed an increasing trend in the population of donkeys signifying the importance and inclusion of donkeys into farmer's herd as adaptation strategy. The results revealed that livestock diversification, making use of migratory approach in search of pasture and water, and sale of livestock before the onset of drought were key adaptation strategies developed by farmers in Kgalagadi-North District. The results also displayed that farmers mainly used to practice different strategies such as saving food and seeds, use of drought tolerant crops, diversifying crop varieties and changing of planting dates to overcome the irregularity of rainfall. Results revealed that farmers mostly used to pray for rains and involved in environmental management for adaptation and mitigation to climate change. It seems that adaptation and mitigation measures employed by farmers helped them to enhance resilience and reduce vulnerability. We suggest that the experience of farmers for adaptation and mitigation to climate change plays a crucial role in scientific research and sustainable development.

\section{Introduction}

Climate change is a real threat to the global community throughout the world (Masipa, 2017). Climate variability and change are among the greatest challenges for sustainable development (IPCC, 2007). This paper examines the indigenous knowledge of farmers to cope up with climate change, their experience on various indicators of climate variability, and its effects on the livelihoods of the local people. Climate change is a serious challenge in Africa because it affects food security and the livelihoods of the farming communities
(O'Farrell et al., 2009). Climate change causes a rise in average surface temperatures on earth leading to the alteration of rainfall and temperatures that affect negatively the agricultural production. In southern Africa, climate variability and change are linked to the declining patterns of rainfall, increased drought frequencies, floods, and extreme temperature (Lesolle, 2012).

Botswana is prone to climate change due to its fragile environments and semi-aridity (Botswana Guardian Newspaper, 2001). Botswana's vulnerability to climate change is most likely intensify the existing burdens that further lead to 
significant changes in terms of indigenous vegetation and rangeland coverage. The impact of climate change can affect considerably the species types, composition and their distribution, as well as the livelihoods of the farming communities who are depending on the rangeland components of the natural resources (Naidoo et al., 2013). Prolonged drought conditions have caused massive loss of livestock and notably affected the livelihoods of the livestock producers (Opiyo et al., 2015). Despite Botswana's extensive rangeland coverage, climate change might pose difficulty in terms of providing enough feed for livestock production and receiving adequate rainfall for cropping.

Climate change is critical for the economy of Botswana and livelihoods of its people (Lesolle, 2012). It has been agreed that the Emissions of Greenhouse Gases contribute to the Global warming causing the Greenhouse effect and associated climate change. Initial efforts in addressing the problem of climate change has revolved around the effects of greenhouse gases (GHGs) in the atmosphere (Nyong et al., 2007). Even if this stabilization was achieved, the impacts of climate change would still be felt because GHG is not the only factor contributing to climate change but there is also a combination of other factors. These factors include variations in solar radiation, the earth's orbit and reflectivity of the earth's surface, atmosphere, oceans, mountains, buildings, continental drift and changes in greenhouse gas concentrations (Smith, 2013). Hence, as climate change and its effects can last for many years, adaptation and mitigation strategies are necessary.

Smith et al. (1996) argued that adaptation is a central component of climatic change. Adaptation to climate change is critical and of much concern in countries like Botswana where exposure is expected to be high (Hassan et al., 2008). However, for effective results, the process of adaptation and mitigation must be integrated to overcome the problem posed by climate change. According to the IPCC Fourth Assessment Report (2007), effective adaptation and mitigation strategies are necessary in minimizing environmental changes, improving economic growth and enhancing social development. Adaptation and mitigation to climate change is not a new concept in Botswana. This is due to the interdependence between the well-being of people and the physical environment. Exposure to climate variability, especially drought is a major challenge to the population of Botswana. According to Dube (2003), frequent droughts in Botswana occurred every 3-5 years over the last 65 years. The fact that the communities have survived these droughts shows that a range of local and societal coping mechanisms might have evolved. These mechanisms are referred to as either indigenous knowledge or local knowledge and such knowledge is unique to every society (Dube, 2003).

Berkes (1993, 2012) stated that indigenous knowledge is a collective form of knowledge, practice and belief, evolving by adaptation processes and handed down through generations by cultural transmission. Previous evidences (The IPCC's Fourth Assessment Report, 2007; Parry et al., 2007) have also shown that 'indigenous knowledge is a basis for adaptation and mitigation strategies' in response to environmental changes. As a result, indigenous knowledge is more recognized as an important source of information on environmental and climate related issues (Egeru, 2012).

In Botswana, information on indigenous knowledge of farmers in terms of adaptation and mitigation to climate change is limited, except in the Okavango and Kweneng regions (Kgosikoma et al., 2018). As a result, this research aims to understand the indigenous knowledge of farmers in terms of adaptation and mitigation to climate change in the Kgalagadi-North District, Botswana. The objectives of this study were: (1) to understand perceptions of farmers about climate change; (2) to assess the impacts of climate change on trends of agricultural production; and (3) to assess the experience of farmers on climate change adaptation and mitigation strategies.

\section{Methodology}

\section{Study area}

Kgalagadi- North is a sub-District of Kgalagadi District in southwest Botswana. It is composed of 14 villages (Statistics Botswana, 2014). The total area of the District is $72,400 \mathrm{~km}^{2}$ with a population of 20,484 and 5,561 households (Statistics Botswana, 2014). The elevation of the study area has an average of $915 \mathrm{~m}$ above sea level. The vegetation types include open savanna, shrubs and tree savanna. The average annual precipitation is about $25 \mathrm{~cm}$ (9.8 in), most of which is received from November to May (Singh, 2011). Out of the total population in the District, 3,353 residents were involved in agriculture (Statistics Botswana, 2014). Generally, the District has 10,530 workers of which 6,334 males and 4,196 females (Statistics Botswana, 2014).

\section{Methods}

In January 2019, interviews of households were carried out in five most populated villages in the Kgalagadi- North District, southwest Botswana. Fifteen households per village were selected, among those residents involved in Agriculture, using a purposive sampling method guided by the village household register book with the assistance of the 
extension officers. The research focused on participants whose ages were equal to 50 and more years old.

A total number of 75 households were interviewed from the five villages, which were selected and an equal number of sample sizes (i.e., 15 households per village) were taken from the five villages. All of the interviewed households were visited, and the household heads were the ones who filled out the questionnaires for this study. The questionnaires were translated to the respondent's local language for ease of understanding and those who were not able to read and write were assisted with reading and writing by the first author. A focus group discussion was also conducted and the selection for interviewees was guided by the village leaders. Further discussions were also held with key informants such as the District heads of departments of Agricultural Development and Food Security using the same questionnaire applied to farmers. Such key informant interview using the same questionnaire applied to farmers was helpful in identifying extension officers who were working in each study village. Five extension officers were interviewed, i.e., one extension officer per each study village. The interviews with extension officers were important as they provided more information about the context of agriculture, livestock keeping practices, livelihood activities and the way the local communities adapted to various risks caused by climate change.

Generally, this study used a qualitative method. Semi-structured questionnaire was used to obtain appropriate information related to the perceptions of households about climate change, its impact, local adaptation and mitigation measures by farmers in the studied villages.

\section{Data Analysis}

The data collected through household survey were analysed using descriptive statistics. Number of respondents and percentages were used in presenting the analyzed data.

\section{Results}

All of the respondents mentioned that they were aware of the occurrence of climate change (Table 1). Almost all of the respondents $(96 \%)$ also reported that rainfall was irregular over the last 30 years. Of the total number of respondents about $87 \%$ of them reported that temperature was increasing.

All respondents $(100 \%)$ stated that the onset and timing of rainfall was late with early cessation over the last 30 years in their localities. Similarly, participants of the focus group discussion perceived that temperature was increasing with irregular patterns of rainfall over the last 30 years.
Table 1: Perception of respondents on indicators of climate change in Kgalagadi-North District, southwest Botswana.

\begin{tabular}{lll}
\hline $\begin{array}{l}\text { Indicators of } \\
\text { climate change }\end{array}$ & \multicolumn{2}{l}{ Households responses $(\mathbf{n = 7 5})$} \\
\cline { 2 - 3 } & $\begin{array}{l}\text { Number of } \\
\text { respondents }\end{array}$ & $\begin{array}{l}\text { \% } \\
\text { Respondents }\end{array}$ \\
\hline $\begin{array}{l}\text { Awareness of } \\
\text { climate change }\end{array}$ & 75 & 100 \\
$\begin{array}{l}\text { Increasing } \\
\text { temperature }\end{array}$ & 65 & 87 \\
Prolonged drought & 40 & 53 \\
$\begin{array}{l}\text { Irregular rainfall } \\
\text { Strong wind }\end{array}$ & 72 & 96 \\
\hline
\end{tabular}

All the respondents mentioned that the number of hot days, frequency of drought and length of the dry season had increased over the last 30 years (Table 2). All of them also believed that the length of the rainy season and rain distribution had decreased over the last 30 years and similar responses were indicated by the focus group participants. All respondents and FGD participants perceived that the duration of the dry season was increased over the last 30 years.

Table 2. Perceptions of respondents on trends of climate change in Kgalagadi-North District, southwest Botswana.

\begin{tabular}{|c|c|c|c|c|}
\hline \multirow{3}{*}{ Variables } & \multicolumn{4}{|c|}{$\begin{array}{l}\text { Perceived trends of climate change } \\
\text { over the last } 30 \text { years }\end{array}$} \\
\hline & \multicolumn{2}{|c|}{ Increased } & \multicolumn{2}{|c|}{ Decreased } \\
\hline & $(n=75)$ & $\%$ & $(n=75)$ & $\%$ \\
\hline No. of hot days & 74 & 99 & & \\
\hline $\begin{array}{l}\text { Frequency of } \\
\text { drought }\end{array}$ & 75 & 100 & & \\
\hline $\begin{array}{l}\text { Change in } \\
\text { rainfall amount }\end{array}$ & 69 & 92 & 6 & 8 \\
\hline $\begin{array}{l}\text { Length of rainy } \\
\text { season }\end{array}$ & 1 & 1 & 75 & 100 \\
\hline $\begin{array}{l}\text { Rain } \\
\text { distribution }\end{array}$ & & & 75 & 100 \\
\hline $\begin{array}{l}\text { Length of dry } \\
\text { season }\end{array}$ & 75 & 100 & & \\
\hline
\end{tabular}

About $44 \%$ of the respondents believed that wildfire was the main cause of climate change in their localities (Table 3). This was followed by a group of respondents $(37 \%)$, who mentioned that they did not know the root causes of climate change. Most of the participants of focus group discussions also perceived that wildfire is among the major factors triggering climate change in their locality. Some respondents believed that climate change was a curse from God. 
Table 3. Perception of respondents on causes of climate change in Kgalagadi-North District, southwest Botswana.

\begin{tabular}{lll}
\hline \multirow{2}{*}{$\begin{array}{l}\text { Causes of climate } \\
\text { change }\end{array}$} & \multicolumn{2}{l}{ Households response $(\mathbf{n = 7 5})$} \\
\cline { 2 - 3 } & $\begin{array}{l}\text { Number of } \\
\text { respondents }\end{array}$ & $\begin{array}{l}\text { \% } \\
\text { Respondents }\end{array}$ \\
\hline Do not know & 28 & 37 \\
Deforestation & 5 & 7 \\
Wildfire & 33 & 44 \\
Livestock & 2 & 3 \\
Industries & 19 & 25 \\
Use of vehicles & 17 & 23 \\
Curse from God & 9 & 12 \\
\hline
\end{tabular}

All the respondents mentioned that milk production had decreased over the last 30 years. Almost all the respondents (93\%) said that the number of calves per cow and number of kids per doe showed a declining trend over the last 30 years (Table 4). Similarly, about $99 \%$ of the respondents stated that forage production was in a decreasing trend.
Out of the total number of respondents, about $97 \%$ of them mentioned that feed costs had increased over the last 30 years.

Almost all the respondents (99\%) mentioned that cattle mortality had increased over the last 30 years (Table 5). About $52 \%$ of the respondents stated that they did not see any change in terms of mortality of donkeys over the last 30 years. Respondents perceived that donkeys were performing better than cattle, goats and sheep under changing climate. Generally, about $77 \%$ of the respondents perceived that cattle population was in a declining trend over the last 30 years and highly vulnerable to climate change. Similarly, participants of the focus group discussions also confirmed that cattle population had decreased over the last 30 years while the population of donkeys increased over the same period.

All the respondents mentioned that invasive plants, food insecurity of households and grassland degradation had increased over the last 30 years in their localities. Moreover, the great majority of respondents perceived that pests and ticks as well as drying of water sources had increased.

Table 4: Perception of respondents on trends of livestock production in Kgalagadi-North District, southwest Botswana.

\begin{tabular}{|c|c|c|c|c|c|c|c|c|}
\hline \multirow{3}{*}{ Variables } & \multicolumn{8}{|c|}{ Perceived trends over the last 30 years } \\
\hline & \multicolumn{2}{|l|}{ Increased } & \multicolumn{2}{|l|}{ Decrease } & \multicolumn{2}{|l|}{ No change } & \multicolumn{2}{|l|}{ Do not know } \\
\hline & $\begin{array}{l}\text { No. of } \\
\text { respondents }\end{array}$ & $\%$ & $\begin{array}{l}\text { No. of } \\
\text { respondents }\end{array}$ & $\%$ & $\begin{array}{l}\text { No. of } \\
\text { respondents }\end{array}$ & $\%$ & $\begin{array}{l}\text { No. of } \\
\text { respondents }\end{array}$ & $\%$ \\
\hline Milk production & & & 75 & 100 & & & & \\
\hline No. of calves/cow & & & 70 & 93 & 2 & 3 & 3 & 4 \\
\hline No. of lambs/ewe & 2 & 3 & 40 & 53 & 3 & 4 & 30 & 40 \\
\hline No. of kids/doe & 1 & 1 & 70 & 93 & 3 & 4 & 1 & 1 \\
\hline Feed costs & 73 & 97 & & & & & 2 & 3 \\
\hline Forage production & 1 & 1 & 74 & 99 & & & & \\
\hline
\end{tabular}

Table 5: Perceptions of respondents about impacts of climate change on livestock in Kgalagadi-North District, southwest Botswana.

\begin{tabular}{|c|c|c|c|c|c|c|c|c|}
\hline \multirow{3}{*}{$\begin{array}{l}\text { Perceived impacts of } \\
\text { climate change }\end{array}$} & \multicolumn{8}{|c|}{ Perceived trends over the last 30 years $(n=75)$} \\
\hline & \multicolumn{2}{|l|}{ Increased } & \multicolumn{2}{|l|}{ Decreased } & \multicolumn{2}{|l|}{ No change } & \multicolumn{2}{|c|}{ I do not know } \\
\hline & Respondent & $\%$ & Respondent & $\%$ & Respondent & $\%$ & Respondent & $\%$ \\
\hline Cattle mortality & 74 & 99 & & & & & 1 & 1 \\
\hline Goats mortality & 73 & 97 & & & 1 & 1 & 1 & 1 \\
\hline Sheep mortality & 47 & 63 & 1 & 1 & & & 27 & 36 \\
\hline Donkeys mortality & 26 & 35 & 2 & 3 & 39 & 52 & 8 & 10 \\
\hline Cattle population & 5 & 7 & 58 & 77 & & & 12 & 16 \\
\hline Goats population & 28 & 37 & 23 & 31 & & & 24 & 32 \\
\hline Donkeys population & 27 & 36 & 3 & 4 & & & 45 & 60 \\
\hline Sheep population & 10 & 13 & 6 & 8 & & & 59 & 79 \\
\hline
\end{tabular}


Table 6: Perception of respondents about impacts of climate change on crop yield, range resources and livelihoods of households in Kgalagadi-North District, southwest Botswana.

\begin{tabular}{lllllll}
\hline \multirow{2}{*}{ Parameters } & Increased & & Decreased & No change \\
\cline { 2 - 6 } & Respondents & \% & Respondents & \% & Respondents & \% \\
\hline Crop yield & 1 & 1 & 69 & 92 & & \\
Invasive plants & 75 & 100 & & 4 & 43 & 37 \\
Tree mortality & 29 & 39 & 3 & 2 & 1 \\
Pests and ticks & 73 & 97 & & & \\
Drying of water sources & 74 & 99 & & & \\
Food insecurity of households & 75 & 100 & & & \\
Grassland degradation & 75 & 100 & & & & \\
\hline
\end{tabular}

About $92 \%$ of the respondents mentioned that crop yields had decreased, which also coincides with the focus group discussions, who also stated that crop yields were in a declining trend over the last 30 years (Table 6).

Table 7: Perception of respondents regarding their adaptation practices to climate change in KgalagadiNorth District, southwest Botswana.

\begin{tabular}{|c|c|c|}
\hline $\begin{array}{l}\text { Perceived adaptation } \\
\text { practices to CC }\end{array}$ & $\begin{array}{l}\text { Respondents } \\
(n=75)\end{array}$ & $\%$ \\
\hline Livestock diversification & 62 & 83 \\
\hline Crop diversification & 56 & 75 \\
\hline $\begin{array}{l}\text { Use of disease and pest } \\
\text { resistant varieties }\end{array}$ & 12 & 16 \\
\hline Saving food and seeds & 51 & 68 \\
\hline $\begin{array}{l}\text { Migration/mobility in search of } \\
\text { pasture and water }\end{array}$ & 52 & 69 \\
\hline $\begin{array}{l}\text { Selling livestock before onset } \\
\text { of drought }\end{array}$ & 44 & 59 \\
\hline $\begin{array}{l}\text { Supplement with emergency } \\
\text { feeds (acacia pods, melons, } \\
\text { bran) }\end{array}$ & 30 & 40 \\
\hline Seek for employment & 34 & 45 \\
\hline Involve in petty trade & 8 & 11 \\
\hline Change of planting dates & 23 & 31 \\
\hline Plantation of trees & 8 & 11 \\
\hline $\begin{array}{l}\text { Build water harvesting } \\
\text { practices(boreholes) }\end{array}$ & 15 & 20 \\
\hline $\begin{array}{l}\text { Use of drought tolerant animal } \\
\text { species }\end{array}$ & 32 & 43 \\
\hline $\begin{array}{l}\text { Use of drought tolerant crop } \\
\text { varieties }\end{array}$ & 51 & 68 \\
\hline $\begin{array}{l}\text { Transporting water for cattle to } \\
\text { the far rangelands }\end{array}$ & 17 & 23 \\
\hline $\begin{array}{l}\text { Use of organic fertilizer } \\
\text { (manure) }\end{array}$ & 8 & 11 \\
\hline Vaccination & 6 & 8 \\
\hline
\end{tabular}

Most respondents (83\%) mentioned that they had diversified their livestock species to adapt to the impact of climate change (Table 7). Whereas $75 \%$ of the respondents said that they used to practice crop diversification to adapt to the changing condition of climate. Others said that they used to practice different strategies such as saving food and seeds $(68 \%)$, migration in search of pasture and water $(69 \%)$, sell of livestock before the onset of drought $(59 \%)$ and keeping drought tolerant livestock species (68\%) (Table 7).

Some of the respondents (53\%) mentioned that they used to pray for rains to pour as a mitigation strategy to climate change. About $47 \%$ of the respondents said that they engaged in environmental management activities to mitigate the impact of climate change. Similarly, most of the participants of the focus group discussion mentioned that they used to pray for rains as well as engaged in environmental management activities as ways of mitigating the impact of climate change (Table 8).

Table 8: Perceptions of respondents on mitigation strategies to climate change in Kgalagadi-North District, southwest Botswana.

\begin{tabular}{lll}
\hline $\begin{array}{l}\text { Perceived mitigation } \\
\text { strategies to CC }\end{array}$ & $\begin{array}{l}\text { No. } \\
\text { Respondent }\end{array}$ & $\begin{array}{l}\% \\
\text { Respondents }\end{array}$ \\
\hline $\begin{array}{l}\text { Environmental } \\
\text { management }\end{array}$ & 35 & 47 \\
$\begin{array}{l}\text { Soil conservation } \\
\text { Reduce the use of } \\
\text { chemicals }\end{array}$ & 4 & 5 \\
$\begin{array}{l}\text { Plantation of trees } \\
\text { Praying for rains }\end{array}$ & 18 & 4 \\
\hline
\end{tabular}

\section{Discussion}

Results from Table 1 depicts that almost all of the respondents (96\%) indicate that rainfall was irregular over the last 30 years. The observations of respondents agree with the findings of Gommes and Petrassi (1996), who pointed out that rainfall fluctuations with varying lengths and intensities are common to arid and semi-arid regions of Africa. According to most respondents (87\%), the 
temperature was increasing over the last 30 years. In the current finding, the perception that temperature has been on the rise is supported by Maddison (2006), who reported the perception of farmers that suggested that an increase in the trend of temperature with a declining amount of precipitation in some African countries. Similarly, Roco et al. (2014) stated that a prevailing perception in many agricultural areas is that temperature is rising while precipitation is decreasing. According to the reflection of all respondents, the onset and timing of rainfall is late with early cessation over the last three decades. Furthermore, all respondents indicate that the duration of rainy season and rain distribution are decreased over time. The findings are consistent with the results reported by Juana et al. (2013), who pointed out that farmers in Sub-Saharan Africa have experienced a similar situation in terms of the delay in the timing of rainfall and early cessation. It has also been shown that farmers in Southern Africa experience a decrease in rainfall pattern over years (Fauchereau et al., 2003).

About $44 \%$ of the respondents believed that wildfire was a major driver of climate change in their localities. The current results are in agreement with the work of Berwyn (2018), who points out that wildfire most likely contributes to the global warming as it emits carbon dioxide and other greenhouse gases to the atmosphere. Furthermore, wildfires can also damage forests that would have removed $\mathrm{CO}_{2}$ from the air (Berwyn, 2018). According to the Australian Academy of Science (2010), human interference is the primary cause of global warming.

All respondents' perceptions indicate that milk production was in a declining trend over the last 30 years. Similarly, about $93 \%$ of the respondents believed that the number of calves per cow and number of kids per doe were in a declining trend over the last 30 years. The findings are in agreement with Mader (2012) and Nardone et al. (2010), who have reported the vulnerability of livestock because of heat stress on animals resulting in reduced productivity. Barati et al. (2008) and Hansen (2007) also states that heat stress affects oocyte growth and quality, impairs embryo development, and pregnancy rate in cows and pigs. Almost all of the respondents mentioned that cattle mortalities were increased. Angassa and Oba (2007) have reported a similar case in southern Ethiopia, suggesting that repeated droughts caused severe mortalities of cattle between 1983 and 2003. Generally, about $77 \%$ of the respondents mentioned that the cattle population decreased and was highly vulnerable to climate change. Similarly, FGD participants confirmed that cattle population in the study villages had decreased while the population of donkeys increased. This is supported by a study conducted by Nyathi (2017), who reported that donkeys are highly prized in the semi-arid region of Zimbabwe due to their importance as drought-tolerant animals as compared to cattle. Smith et al. (2005) also indicated that donkeys have greater ability to tolerate thirst and are able to select a better quality of diet than cattle from the same area of rangelands.

About $92 \%$ of the respondents and all FGD participants confirmed that there is a declining trend in crop yield over the last 30 years. During the focus group discussions, some of the participants stated that they have already deserted ploughing their crop fields because of the failure of crop yields for harvest due to the failure of rain. According to the observations of farmers, climate change adversely affected their crops and this is in agreement with the work of others (Schlenker and Lobell, 2010), who stated that a maize-based system in southern Africa is particularly vulnerable to climate change, with yield losses for South Africa and Zimbabwe predicted to be over 30\%. Nelson et al. (2009) have also reported that rainfall variability and extreme temperatures across Sub-Saharan Africa are likely to decrease wheat productivity by $35 \%$ and that of sorghum by $2 \%$.

All the respondents mentioned that grassland degradation had increased, while forage production was reduced as a result of invasive plants like Prosopis juliflora and a grass species locally known Tlolele. This agrees with CCSP (2008) that suggests that drought might have threatened rangeland productivity and livestock feed supply by reducing the quantity and quality of forage. IUCN (2017) also indicates that invasive species are one of the biggest causes for the loss of biodiversity and species extinctions. Furthermore, the same report has informed that climate change facilitates the spread and establishment of many alien species and creates new opportunities for them to become invasive. Respondents also reported that the drying of water sources have increased over the years. According to the observations of respondents, the drying of boreholes and/or water sources are attributed to the adverse effects of invasive trees as well. Overall, the perceptions of respondents confirm that the presence of Prosopis juliflora in the study areas resulted in the drying up of boreholes next to the invasive tree species. Kevin and Nicholas (2010) indicated that drought induced climate change has an impact on water sources in many African countries. For instance, in support of the observations of respondents concerning the problem caused by Prosopis juliflora, Prasad and Tewari (2016) have stated that the unusual deep root system of the plant can deplete groundwater reserves. The same authors have shown that once the roots of Prosopis reach a 
water source, the roots extend horizontally in the direction of the water flow and end up blocking boreholes or reducing the quantity of water supply from the water sources.

Almost all respondents reflected that pests and ticks had been increasing over the last 30 years in their localities. Similarly, Leonard (2006) has reported that warmer temperatures probably create longer growing seasons and faster growth rates of plants, while increasing the metabolic rate and breeding cycles of insects. In parts of southern African region, a study by Olwoch et al. (2008) have shown that the distribution of tick vector that is causing East Coast Fever Disease increased with increasing temperature.

The experiences of respondents indicate that they used to diversify their livestock species, make use of migratory approach in search of pastures and water as well as sell their livestock ahead of the onset of drought to adapt to the impact of climate change. These adaptation strategies are widely practiced in Africa as some studies (Ng'ang'a et al., 2012; Oba, 1997; Tambo, 2016; Megersa et al., 2014a; Megersa et al., 2014b) have shown the experiences of pastoralists in diversifying their herds, culling drought intolerant livestock species and practicing seasonal migrations in search of pasture and water (Oba, 1998; Angassa and Oba, 2008).

About $75 \%$ of the respondents indicate that they practice crop diversification to adapt to the changing condition of climate. The knowledge of respondents also show that they practice different strategies such as saving food and seeds and make use of drought tolerant crop varieties. These are among the most common adaptation measures practiced by most farmers in Africa. Similarly, Bryan et al. (2009) have indicated that farmers in South Africa practiced planting of different crop varieties and change of planting dates as adaptation strategies to climate change. Furthermore, farmers in South Africa (Gandure et al., 2013), Senegal (Mertz et al., 2009) and Uganda (Egeru, 2012) have adopted early maturing crop varieties as compared to late maturing crop varieties.

The perceptions of farmers also indicated that they used to pray for rains as mitigation strategy to climate change in the study areas. A similar case was reported by Johnson (2018), suggesting that festivities are organized and performed when the severity of drought increased from November to January of each year in Basotho culture where men, women, girls and boys engage in praying for rain. Respondents also mentioned that they used to be involved in various environmental management and conservation activities to mitigate the impact of climate change. Data from several studies (Nyasimi et al., 2014; Kaczan et al., 2013; Bationo and Vlek,
1998; Naab et al., 2012) have shown that agroforestry and zero tillage are being adopted by farmers as mitigation strategy to combat climate change. Similarly, most of the FGD participants mentioned that they used to pray for rains as well as being engaged in environmental management.

\section{Conclusion}

The study concludes by arguing that farmers in the study area were affected by the irregular nature of rainfall, increased temperature and recurrent droughts. The observations of farmers have shown that wildfire was the main factor contributing to climate change. The findings further confirmed that milk production and number of calves per cows were in a declining trend over the last 30 years. Most importantly, the results provide evidence for increased trends of the population of donkeys over cattle signifying the importance of including donkeys in farmers' herd as mitigation strategy to climate change. The observations of farmers have also shown that crop yields were reduced, and crop fields deserted. The broad implication of this study is that the indigenous knowledge and experience of farmers for adaptation and mitigation to climate change play a crucial role in scientific research and sustainable development. Future research should consider the potential role of indigenous knowledge versus empirical evidence regarding the impacts of climate change on the livelihoods of farmers in the study areas. These findings provide a potential mechanism for a sustainable society where policy makers and planners should consider the necessary actions that facilitate to formulate climate change adaptation and mitigation options in the national policy framework and strategies. We suggest public awareness creation to strengthen community resilience and their adaptive capacities to the impacts of climate change in the region.

\section{Acknowledgments}

The authors thank respondents for their cooperation and participation at the time of data collection. We also thank the key informants and officials in the study area for their support during the data collection.

\section{References}

Angassa A. and Oba G. (2008). Herder perceptions on impact of range enclosures, crop farming, fire ban and bush encroachment on the rangelands of Borana, southern Ethiopia. Hum. Ecol. 36: 201215.

Angassa A., Oba, G. (2007). Relating long-term rainfall variability to cattle population dynamics in communal rangelands and a government 
ranch in southern Ethiopia. Agricultural Systems 94: 715-725.

Barati F., Agung, B., Wongsrikeao P., Taniguchi, M., Nagai T., Otoi T. (2008). Meiotic competence and DNA damage of porcine oocytes exposed to an elevated temperature. Theriogenology 69: 767-772.

Bationo A., Vlek P. (1998). The role of nitrogen fertilizers applied to food crops in the Sudano Sahelian zone of West Africa. In Soil Fertility Management in West African Land Use Systems; Renard, G., Neef, A., Becker, K., Oppen, M., Eds.; Margaf Verlag: Weikersheim, Germany, pp. 41-51.

Berkes F. (2012). Sacred ecology (3rd ed.). New York, NY: Routledge.

Berkes F. (1993). Traditional ecological knowledge in perspective. In Traditional Ecological Knowledge: Concepts and Cases, J. T. Inglis (ed.). Ottawa: International Program on Traditional Ecological Knowledge and International Development Research Centre. pp $1-9$.

Berwyn B. (2018). How Wildfires Can Affect Climate Change (and Vice Versa); INSIDECLIMATE NEWS; Retrieved from; https://insideclimatenews.org/news/23082018/ex treme-wildfires-climate-change-globalwarming-air-pollution-fire-management-blackcarbon-co2.

Bryan E., Deressa T.T., G.A. Gbetibouo G.A. and Ringler C. 2009. Adaptation to Climate Change in Ethiopia and South Africa: Options and Constraints. Environmental Science and Policy 12: 413-426.

Climate Change Science Program (CCSP). (2008). The Effects of Climate Change on Agriculture, Land Resources, Water Resources, and Biodiversity in the United States. A Report by the U.S. Climate Change Science Program and the Sub-committee on Global Change Research. U.S. Environmental Protection Agency, Washington, DC, USA.

Dube O. (2003). Impact of climate change, vulnerability and adaptation options: Exploring the case for Botswana through Southern Africa: Botswana Notes and Records, Vol. 35, Retrived from https://www.jstor.org/stable/40980347.

Egeru A. (2012). Role of Indigenous Knowledge in Climate Change Adaptation: A Case Study of the Teso Sub-Region, Eastern Uganda. Indian Journal of Traditional Knowledge 11(2): 217224.

Fauchereau N., Trzaska S., Rouault M. and Richard Y. (2003). Rainfall Variability and Changes in Southern Africa during the 20th Century in the Global Warming Context. Natural Hazards 29:
$139-154$.

Gandure S., Walker S. and Botha J.J. (2013). Farmers' Perceptions of Adaptation to Climate Change and Water Stress in a South African Rural Community. Environmental Development 5(1): 39-53.

Gommes R., Petrassi F. (1996). Rainfall Variability and Drought in Sub-Saharan Africa: Environment and Natural Resources Service (SDRN) FAO Research, Extension and Training Division: Retrieved from http://www.fao.org/nr/climpag/pub/EIan0004_e n.asp.

The Botswana Guardian Newspaper http://www.botswanaguardian.co.bw/news/item/ 3142-climate-change-threats-real-forbotswana.html accessed 22.09.2019

Hansen P.J. (2007). Exploitation of genetic and physiological determinants of embryonic resistance to elevated temperature to improve embryonic survival in dairy cattle during heat stress. Theriogenology 68 (4): pp. S242-S249.

Hassan R., Nkemechena C. (2008). Determinants of African farmers' strategies for adapting to climate changes: multinomial choice analysis. AFJARE. 2(1): 85-104.

International Union for Conservation of Nature (IUCN). (2017). Invasive alien species and climate change; Retrieved from https://www.iucn.org/sites/dev/files/ias_and_cli mate change issues brief final.pdf

IPCC (2007). "What are Climate Change and Climate Variability?" IPCC.

Johnson L.R. (2018). Basotho culture and the prayers for rain: Where climate change converges. Southern African Journal for Folklore Studies. 28. 19. 10.25159/1016-8427/3799.

Juana J. S., Kahaka Z. and Okurut F.N. (2013). Farmers' Perceptions and Adaptations to Climate Change in Sub-Sahara Africa: A Synthesis of Empirical Studies and Implications for Public Policy in African Agriculture. Journal of Agricultural Science 5(4): 2013 ISSN 19169752 E-ISSN 1916-9760 Published by Canadian Center of Science and Education.

Kaczan D., Arslan A. and Lipper L. (2013). Climatesmart agriculture: A review of current practice of agroforestry and conservation agriculture in Malawi and Zambia. Rome: United Nations Food and Agriculture Organization.

Kevin C.U. and Nicholas O. (2010). Impacts of climate change on water resources in Africa: the role of adaptation. African Technology Policy Studies Network. 29.

Kgosikoma K.R., Phatsimo C.L., Kgosikoma O.E. (2018). "Agro-pastoralists' determinants of adaptation to climate change", International 
Journal of Climate Change Strategies and Management, Vol. 10 Issue: 3, pp.488-500, https://doi.org/10.1108/IJCCSM-02-2017-0039.

Leonard A. (2006). Global warming could trigger insect population boom. Live science, Retrieved from http://www.livescience.com.

Lesolle D. (2012). SADC policy paper on climate change: Assessing the policy options for SADC member states. SADC Research and Policy Paper Series. 01/2012.

Maddison D. (2006). The Perception of and Adaptation to Climate Change in Africa (No. 4308), Policy Research Working Paper, Pretoria, South Africa. Available at: <http://econ.worldbank.org>.

Mader T.L. (2012). Impact of environmental stress on feedlot cattle. Western Section, American Society of Animal Science 62: 335-339.

Masipa T.S. (2017). The impact of climate change on food security in South-Africa: current realities and challenges ahead. Jàmbá - Journal of Disaster Risk Studies, ISSN: 2072-845X, 19961421.

Megersa B., Markemann A., Angassa, A., Ogutu, J.O., Piepho, H.P. and Zárate A.V. (2014b). Livestock Diversification: an Adaptive Strategy to Climate and Rangeland Ecosystem Changes in Southern Ethiopia. Hum. Ecol. (2014) 42:509-520, DOI 10.1007/s10745-014-9668-2.

Megersa B., Markemann A., Angassa A and Zárate A.V. (2014a). The role of livestock diversification in ensuring household food security under a changing climate in Borana, Ethiopia. Food Sec. (2014) 6:15-28, DOI 10.1007/s12571-013-0314-4.

Mertz O., Mbow C., Reenberg A. and Diouf A. (2009). Farmers' Perceptions of Climate Change and Agricultural Adaptation Strategies in Rural Sahel. Environmental Management, 43(5): 804816.

Naab J.; Bationo A.; Wafula B.M., Traore P.S.; Zougmore R.; Ouattara M.; Tabo R., Vlek P.L.G. (2012). African Perspectives on Climate Change and Agriculture: Impacts, Adaptation, and Mitigation Potential. In Handbook of Climate Change and Agroecosystems Global and Regional Aspects and Implications; ICP Series on Climate Change Impacts, Adaptation, and Mitigation; Hillel, D., Rosenzweig, C., Eds.; Imperial College Press: London, UK, Volume 2, pp. 85-106. ISBN 978-1-84816-983-8.

Naidoo S., Davis C., Van Garderen E.A. (2013). Forests, rangelands and climate change in southern Africa. Food and Agriculture Organization of the United Nations Rome, Italy.

Nardone A., Ronchi B., Lacetera N., Ranieri M.S. Bernabucci U. (2010). Effects of climate change on animal production and sustainability of livestock systems. Livest. Sci., 130, pp. 5769.Sirohi, S. Michaelowa A. (2007). Sufferer and cause: Indian livestock and climate change Climatic Change, 85, pp. 285-298.

Nelson G., Rosegrant M. Koo J., Robertson R., Sulser T., Zhu T., Ringler C., Msangi S., Palazzo A., Batka M., Magalhaes M., ValmonteSantos R., Ewing M., Lee D. (2009). Climate change impact on agriculture and costs of adaptation, Washington, DC: International Food Policy Research Institute (IFPRI).

Ng'ang'a S.K., Maute F., Notenbaert A., Herrero M. and Moyo S. (2012). Coping Strategies and Vulnerability to Climate Change of Households in Mozambique. CCAFS Working Paper No 28. CGIAR Research Program on Climate Change, Agriculture and Food Security (CCAFS). Copenha-gen, Denmark.

Nyasimi M., Amwata D., Hove L, Kinyangi J., Wamukoya G. (2014). Evidence of impact: Climate-smart agriculture in Africa. Wageningen, Netherlands: CGIAR Research Program on Climate Change, Agriculture and Food Security (CCAFS) and the Technical Centre for Agricultural and Rural Cooperation (CTA).

Nyathi J. (2017). The Boer, donkeys and Zimbabweans. Bulawayo24 news retrieved from https://bulawayo24.com/index-id-opinion-sccolumnist-byo-109230.html.

Nyong A., Adesina F. and Elasha B.O. (2007). The Value of Indigenous Knowledge in Climate Change Mitigation and Adaptation Strategies in the African Sahel. Mitigation and Adaptation Strategies for Global Change, 12(5): 787-797.

Oba G. (1997). Pastoralists' traditional drought coping strategies in Northern Kenya. A Report for the Government of the Netherlands and the Government of Kenya, Euroconsult BV, Arnheim and Acacia Consultants Ltd, Nairobi.

Oba G. (1998). Assessment of indigenous range management knowledge of the Borana pastoralists of Southern Ethiopia. Commissioned by GTZ-Borana Lowland Pastoral Development Program in collaboration with the Oromia Regional Bureau for Agricultural Development. Negelle/Borana, Ethiopia.

O'Farrell P., Anderson P., Milton S. and Dean W. (2009). Human Response and Adaptation to Drought in the Arid Zone: Lessons from Southern Africa. South African Journal of Science, 105(1-2): 34-39.

Olwoch J.M., Reyers B., Engelbrecht F.A., Erasmus, B.F.N. (2008). Climate change and the tickborne disease, Theileriosis (East Coast fever) in sub-Saharan Africa. J. Arid Environ. 72, 108- 
120.

Opiyo F., Wasonga O., Nyangito M., Schilling J. and Munang R. (2015). "Drought adaptation and coping strategies among the Turkana pastoralists of Northern Kenya", International Journal of Disaster Risk Science 6(3): 295-309, doi: 10.1007/s13753-015-0063-4.

Parry M.L., Canziani O.F., Palutikof J. P., van der Linden P.J., and Hanson C.E. (eds.) (2007). Contribution of Working Group II to the Fourth Assessment Report of the Intergovernmental Panel on Climate Change. Cambridge, UK and New York, Cambridge University Press.

Prasad M.N.V. and Tewari J.C. (2016). Prosopis juliflora (Sw) DC; Bioremediation and Bioeconomy, Retrieved from https://www.sciencedirect.com/topics/earth-andplanetary-sciences/phreatophytes.

Roco L., Engler A., Bravo-Ureta B., Jara-Rojas R. (2014). Farm level adaptation decisions to face climatic change and variability: Evidence from Central Chile. Environmental Science and Policy 44: 86-96.

Schlenker W. and Lobell D. B. (2010). Robust negative impacts of climate change on African agriculture. Environmental Research Letters 5(1): 014010-014018.

Singh (2011). Geography. Tata McGraw-Hill Education. p. 12.53. ISBN 978-0-07-107480-3.

Smith J.B. and Lenhont S. (1996). Climate change adaptation policy options. Climate Research 6: 193-201. Sons, New York.

Smith D.G. and Pearson R.A. (2005). A review of the factors affecting the survival of donkeys in semi-arid regions of sub-Saharan Africa. Department of Agriculture and Forestry, University of Aberdeen, Aberdeen, Scotland, UK, $\quad$ AB24 3FX. Email d.g.smith@abdn.ed.ac.uk Centre for Tropical Veterinary Medicine, Easter Bush, Roslin, and Midlothian, Scotland.

Smith R.C. (2013). Uncertainty Quantification: Theory, Implementation, and Applications. Computational Science and Engineering. 12. SIAM. p. 23. ISBN 1611973228.

Statistics Botswana. (2014). Population and housing census 2011 analytical report. Published by Statistics Botswana. Botswana, Gaborone.

Tambo J.A. (2016). Adaptation and resilience to climate change and variability in north-east Ghana. International Journal of Disaster Risk Reduction 17:85-94. https://doi.org/10.1016/j.ijdrr.2016.04.005. 